\title{
THE MUSHROOM AND THE PARASOL
}

\author{
A WEST INDIAN RIDDLE
}

BY

\section{ROBERT WALLACE THOMPSON}

M. J. Beckwith, in Jamaica Anansi Stories, ${ }^{1}$ ) records a Jamaican riddle which seems to be good currency in many of the West Indian territories: - My father have a house up on one post. Answer: Umbrella. In another of her books ${ }^{2}$ ) she registers a more idiomatic dialectal version: My father have a house stand upon one post. Rev. GEORGE E. LAWRENCE ${ }^{3}$ ) found the same riddle in the Leeward Islands (Montserrat?): Me fadah hab a house wid only one upright and twenty rafter. Wha' dat? A Sranan Tongo (Taki-taki, Negro English) variant was discovered by Herskovirs ${ }^{4}$ ) in Suriname: Mi meki wan oso nanga wan postu. 'me make one house with one post'. Answer: Na wan prasoro (parasol). Slight variants are in use in other parts of the West Indies, including those areas where the common language is French Creole.

Miss BEcKwITH pointed out ${ }^{1}$ ) that two versions of this riddle have been documented for East and West Africa; in Suaheli (VELTEN): - I have built me a great house; it stands upon one post; and in Hausa (RATTRAY): - I build a hut with only one post to prop up the roof. It would be difficult to say how widely the umbrella riddle is spread over the African continent, but the similarity between these two East and West African forms and West Indian forms is certainly striking. Naturally the concept of an umbrella equalling a house built on one post or relying on one post to keep the roof up could occur independently to more than one individual and be adopted by more than one people. What is striking is that the joke continues to be made by Africans or by people largely of African origin and does not turn up in the collections of European riddles which I have been able to consult. That the circular umbrella or parasol was in use on the West Coast of Africa in the early eighteenth century and probably earlier

1) Jamaica Anansi Stories, New York, 1924

2) Black Roadways, Chapel Hill, 1929.

s) West Indian Folklore, Proverbs, Riddles, Stories and Songs. Book III. (Typescript) Chichester (after 1946).

4) Melville J. \& Francis S. Herskovits: Surinam Folk-lore, New York, 1936. 
is well known. Fr. LABAT $\left.{ }^{1}\right)$ published an engraving entitled Couronnement du Roy de Juda à la Coste de Guinée au Mois d'Avril, 1725. Amongst the distinguished foreigners attending this coronation - European ambassadors and others anxious to purchase black slaves - sits a Grand du Pays tenant un Parasol, which is round-shaped and wide like our modern beach umbrellas, and quite unlike the rough, irregular leaf-umbrella often used nowadays in various parts of Tropical Africa. In an earlier Africa the umbrella may have been ceremonial as well as functional.

Let us turn now from umbrellas and parasols to mushrooms! In the West Indies the most common generic term for 'mushroom' is a metaphor involving the parasol and, often, a supernatural parasol. Forms such as paragua(s), paragüita(s), paragüito are common in Cuba, the Dominican Republic and Porto Rico. Jumbi umbrella is heard in St. Kitts, Antigua, Montserrat, Trinidad and British Guiana; duppy umbrella in Barbados and Jamaica (where it is restricted to a few areas - junjo is the usual term). The duppy and jumbi are African spirits which have survived in the New World. They are related to the zombi of the French-Creole-speaking islands - the mushroom is parésol zombi in parts of Dominica. A "Christianised" rendering of this form is parésol djab ( $<\mathrm{F}$. diable), heard in St. Lucia. A parallel version is parasol di diablo in the Papiamento of Curaçao. Sranan tongo (Taki-taki) uses a form which fits the umbrella image into a familiar European pattern: todo-prasoro 'toad-parasol' (cf. Eng. toad-stool, Dutch paddestoel etc.). A proverb in the same language ${ }^{2}$ ) plays on this word: Mi no can tro' todo to opo prasoro gi sneki 'I cannot change the toad so that he will open a parasol for the snake'.

The supernatural nature of the mushroom is well attested in the folklore of both Europe and Africa and the fairy ring of the pasture is as aweinspiring to the rural Irishman as mushrooms are to the Fulani of Adamawa ${ }^{3}$ ) who dislike them "because they spring up overnight, the implication being that they are associated with nocturnal spirits". It is therefor difficult to decide whether the supernatural umbrella-mushroom came wholly from Africa, or whether it is a hybrid Eurafrican growth which developed in the West Indies. It is not likely that the image is purely European as it is not documented in the classical works on the dialectology of the colonising nations of Europe. It certainly does not appear in Gilliéron's ${ }^{4}$ ) nor in Peninsular Spanish which is singularly poor in terms for 'mushroom' as compared with say the sub-dialects of Porto Rico and $\mathrm{Cuba}^{5}$ ), nor in the English of the British Isles which has bequeathed 'mushroom' alone to the New England States $\left.{ }^{6}\right)$. Even if the Africanists

1) J.-P. LABAT, in his Voyage du Chevalier ..., Paris, 1730.

2) Herskovirs op. cit., Taki-taki proverb no. 104.

3) Letter from Dr. J. BERRY, School of Oriental and African Studies, University of London.

4) J. Gilliḱron \& E. Edmont: Atlas linguistique de la France, Paris, 1903-1910.

5) T. Navarro Tomas: El español en Puerto Rico. Rio Piedras, P. R., 1948, map 44. Also communications from Ing. Julian AcuÑa, Estación experimental agronómica, Santiago de las Vegas, Cuba.

$\left.{ }^{6}\right)$ H. Kurath: Linguistic Atlas of New England, Providence, L.I. 1939-1943, map 279. 
cannot easily turn up evidence of the widespread occurrence of our metaphor in the West African dialects or in slavers' jargon, or in a West African lingua franca (perhaps on a creolised Portuguese base, $c f$. the beginnings of Papiamento $\left.{ }^{1}\right)$ ), it would still seem unlikely that it was conceived in the West Indies unless it could be shown that it spread from island to island and territory to territory, carried by planters, buccaneers and slaves in the movements of population round the Caribbean in the 17th and 18th Century. Even then, it would be difficult to show how it has been adopted by at least three creolised European languages (English, French and Portuguese).

Returning once more to the riddle which began this note, we present a Haitian version ${ }^{2}$ ) which expects a different answer: Kay a mwê grâ, sô sèl poto ki kêbe $i$ 'House to me big, it is a single post which supports it'. Answer: $D j \delta d j 6$, 'mushroom'. The variant yonyón is found in one small area of Porto Rico ${ }^{3}$ ) and in Jamaica junjo is used in all parishes. The Haitian form has been recorded in Dominica ${ }^{4}$ ) side by side with dialectal $j 6 j 6$ which lacks the d-element. Not only can these last forms designate 'mushroom' in Dominica but also, according to dialect, (improvised) 'plaything', „,that is, an object, such as a rag or piece of wood to which a child attaches a special affection". This secondary meaning is not semantically distant from $z \tilde{\jmath} z \tilde{\jmath}$ 'twiddly-bit' 'thingummy-bob' in the French Creole of Mauritius ${ }^{5}$ ) which arose from the contract or French sailors, slavers and planters with Malgache and African (including West African) slaves. Mauritian $z \tilde{z} z \tilde{j}$ and Dominican $j 6 j 6$ may of course not be related. Mauritian „umbrella" words are parapli, frasol (= parasol) chatta (of Indian origin);

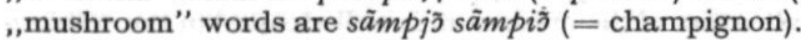

It seems to me, then, that the ummbrella riddle, like many other West Indian riddles, came to the New World from Africa and that the umbrellamushroom could well be an Africanism which has survived in many territories and several dialects of the West Indies.

It will be easier for us to solve such problems as these when the linguistic surveys at present being conducted by the University of Amsterdam and the University College of the West Indies have yielded up their harvest and when we know more of the slaves' Afrikaanse koinè alluded to by LICHTVELD ${ }^{6}$ ) in a recent number of this periodical.

1) T. Navarro Tomas: Observaciones sobre el papiamento, Nueva Revista de Filología Hispánica 7, México, 1953, nrs. 1-2.

2) M. P. HyPPOLITE: Littérature populaire haĩtienne, Port-au-Prince, 1950.

3) Navarro Tomas op. cit., map 44.

4) Information supplied by Mr. Douglas Taylor, Magua, Dominica.

s) Information on Mauritian creole supplied by Mr. I. Richardson, S.O.

A.S., London.

6) Lou Lichtveld : Enerlei Creools? W. I Gids 35, 1954, p. 69. 